\title{
Green manure, seed inoculation with Herbaspirillum seropedicae and nitrogen fertilization on maize yield
}

\author{
Joseani S. Ávila ${ }^{1}$, Joilson S. Ferreira ${ }^{2}$, Joelma S. Santos ${ }^{1}$, Pablo A. da Rocha ${ }^{3} \&$ Vera L. D. Baldani $^{4}$ \\ ${ }^{1}$ Universidade Estadual do Sudoeste da Bahia/Programa de Pós-Graduação em Agronomia. Vitória da Conquista, BA, Brasil. Email: joseanis.avila@gmail.com \\ (Corresponding author) - ORCID: 0000-0002-4345-9976; joelmassbio@gmail.com - ORCID: 0000-0002-0475-9503 \\ ${ }^{2}$ Universidade Estadual do Sudoeste da Bahia/Departamento de Fitotecnia e Zootecnia. Vitória da Conquista, BA, Brasil. Email: joilsonsf@yahoo.com.br - \\ ORCID: 0000-0001-7324-969X \\ ${ }^{3}$ Instituto Federal de Educação, Ciência e Tecnologia Baiano/Campus de Uruçuca. Uruçuca, BA, Brasil. Email: pabloconsultap@gmail.com - ORCID: 0000- \\ 0002-8113-1605 \\ ${ }^{4}$ Empresa Brasileira de Pesquisa Agropecuária/Centro Nacional de Pesquisa em Agrobiologia. Seropédica, RJ, Brasil. Email:verabaldani@yahoo.com.br - ORCID: \\ 0000-0002-6125-5811
}

\begin{abstract}
The current need for increase crop yields requires the supplying of nutrients, mainly nitrogen, which increases the production cost, requiring the search for alternative products, such as seed inoculation with diazotrophic bacteria and green manures. In this context, the objective of this study was to evaluate the effect of green manure, seed inoculation with Herbaspirillum seropedicae, and nitrogen fertilization on the productive performance of maize crops. The experiment was conducted at the district of Estiva, in the

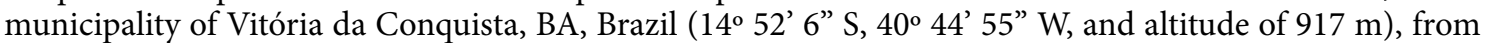
December 2015 to August 2016. A randomized block design with four repetitions was used, in a $2 \times 2 \times 2$ factorial arrangement, consisting of presence or absence of green manure (velvet bean), seed inoculation with Herbaspirillum seropedicae (strain ZAE94), and mineral nitrogen fertilization (120 $\left.\mathrm{kg} \mathrm{ha}^{-1}\right)$. The maize ear length and diameter, number grains per row, ear weight without husks, cob weight, and grain yield were evaluated. A significant triple interaction was found for all evaluated variables. The use of green manure presented better results than the control. Velvet bean can be used as a green manure, as an alternative to soil mineral fertilization without yield losses.
\end{abstract}

Key words: Zea mays L., soil cover plants, nitrogen biological fixation, Mucuna sp.

\section{Adubação verde associada à inoculação com Herbaspirillum seropedicae e adubação nitrogenada na produtividade do milho}

RESUMO: Atualmente, a necessidade de aumento da produtividade das culturas depende do fornecimento principalmente do nitrogênio e isso onera o custo de produção, sendo necessária a busca por produtos alternativos, como a inoculação com diazotrophic bacteria e a adubação verde. Diante disso, objetivou-se neste estudo avaliar o efeito da adubação verde, inoculação com Herbaspirillum seropedicae e adubação nitrogenada no desempenho produtivo do milho. O experimento foi conduzido no povoado da Estiva, município de Vitória

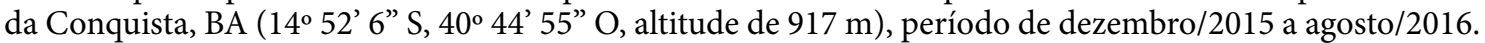
Utilizou-se delineamento em blocos casualizados, esquema fatorial $2 \times 2 \times 2$, com quatro repetições. Os fatores foram: Adubação verde (com e sem mucuna preta), inoculação (com e sem inoculação de Herbaspirillum seropedicae, estirpe ZAE94) e nitrogênio mineral (com e sem nitrogênio mineral na dose de $120 \mathrm{~kg} \mathrm{ha}^{-1}$ ). Avaliou-se, comprimento e diâmetro de espiga, número de grãos por fileira, peso da espiga despalhada, peso de sabugo e a produtividade de grãos. Houve interação tripla para todas as variáveis analisadas. A utilização de adubação verde foi superior em relação à testemunha. A mucuna preta pode ser utilizada como alternativa à adubação mineral sem perdas de produtividade.

Palavras-chave: Zea mays L., cobertura vegetal, fixação biológica de nitrogênio, mucuna 


\section{INTRODUCTION}

Maize is an important crop in the production chain of several sectors. It is the most produced and consumed grain in the world. Approximately $66.5 \%$ of the world's maize production is concentrated in three countries: United States, China, and Brazil (CONAB, 2017). High maize yields can be reached using a balanced soil nitrogen fertilization (Malavolta, 2006; Zambolim et al., 2012).

Nitrogen is one of the most complex nutrients, which is highly dependent on edaphoclimatic conditions to be absorbed by the plants (Primavesi, 2002). Moreover, it is not totally absorbed by the plants when applied; part of it is lost in the soil-plant-atmosphere system mainly by volatilization, leaching, erosion, and denitrification.

Alternative nitrogen sources to soil mineral fertilization have been used to reduce environmental impacts and production cost, such as biological nitrogen fixation and green manures (Malavolta, 2006). Biological nitrogen fixation occurs due to symbiotic relationships between rhizobia and legume species, which can supply $94 \%$ of the nitrogen required by soybean crops (Hungria et al., 2006). However, several studies have shown the use of biological nitrogen fixation for non-leguminous crops. According to Kappes et al. (2013), the interaction between diazotrophic bacteria and plants is an important strategy to decrease nitrogen fertilizer applications.

Leguminous crop species have high specificity for biological nitrogen fixation and can be used as green manures; they present high potential to accumulate nitrogen, and low $\mathrm{C}$ to $\mathrm{N}$ ratio (fast mineralization of organic matter), and promote nutrient cycling, mainly nitrogen (Rodrigues et al., 2012).

Considering the lack of studies on green manures combined with seed inoculation with diazotrophic bacteria and soil nitrogen fertilization for the region of Vitória da Conquista, $\mathrm{BA}$, Brazil, the objective of this study was to evaluate the effect of the use of green manure (velvet bean), seed inoculation with Herbaspirillum seropedicae, and soil nitrogen fertilization on the productive performance of maize crops.

\section{Material ANd Methods}

The experiment was conducted at the district of Estiva, in the municipality of Vitória da Conquista, BA, Brazil (14 $52^{\prime} 6^{\prime \prime} \mathrm{S}$, $40^{\circ} 44^{\prime} 55^{\prime \prime} \mathrm{W}$, and altitude of $917 \mathrm{~m}$ ), from December 2015 to August 2016. The local mean annual of temperature was $20.2^{\circ} \mathrm{C}$, and the mean annual rainfall depth was $733.9 \mathrm{~mm}$, concentrated from November to March (SEI, 2013).

The experiment area had been grown with tomato, velvet bean, and sweet pepper, and after a fallow of five months the experiment was implemented.

The soil of the area was classified as Typic Hapludox and presented sandy clay loam texture. The soil $0-20 \mathrm{~cm}$ layer presented the following chemical characteristics before the soybean crops: $\mathrm{pH}\left(\mathrm{H}_{2} \mathrm{O}\right)$ of $5.3 ; 52 \mathrm{mg} \mathrm{dm}^{-3}$ of $\mathrm{P} ; 6.4$ cmolc $\mathrm{dm}^{-3}$ of sum of bases; $6.6 \mathrm{cmolc} \mathrm{dm}^{-3}$ of effective cation exchange capacity (CEC); $13.6 \mathrm{cmolc} \mathrm{dm}^{-3}$ of CEC; and base saturation of $47 \%$. Liming was carried out using $2 \mathrm{Mg} \mathrm{ha}^{-1}$ of dolomitic limestone at three months before the experiment implementation, as recommended by Ribeiro et al. (1999).
A randomized block experimental design with four repetition was used, in a $2 \times 2 \times 2$ factorial arrangement, consisting of presence or absence of green manure (velvet bean), inoculation with and Herbaspirillum seropedicae (strain ZAE94), and mineral nitrogen fertilization $\left(120 \mathrm{~kg} \mathrm{ha}^{-1}\right)$, forming eight treatments, totaling 32 plots.

Each plot consisted of five 3-meter rows spaced $0.7 \mathrm{~m}$ apart, forming an area of $8.4 \mathrm{~m}^{2}$ per plot. The evaluation area was the three central rows of each plot, disregarding $0.5 \mathrm{~m}$ of each end of the rows. The plots were spaced $0.3 \mathrm{~m}$, and the blocks $2.0 \mathrm{~m}$ apart.

The velvet bean was sown at 103 days before the maize sowing for the plots with green manure treatment.

The velvet bean seeds were inoculated with symbiotic diazotrophic bacteria before sowing, using the species Bradyhizobium elkanii, strain BR2811 (SEMIA 6158), as recommended by the Ministério da Agricultura, Pecuária e Abastecimento (MAPA). The inoculant was in turf medium and was applied at dose of $110 \mathrm{~g}$ per $20 \mathrm{~kg}$ of seeds.

The velvet bean seeds were manually sowed to furrows opened with hoes, using six seeds per linear meter, with spacing of $0.7 \mathrm{~m}$ between furrows.

Velvet bean samples were collected at 96 days after sowing to evaluate their fresh green, dry weight, and total nitrogen. The sample collection was done by randomly launching a $0.25-\mathrm{m}^{2}$ square frame in the plots, and cut the plants inside the frame at ground level. The plants were weighed in a digital balance, placed in paper bags, and taken to a forced air-circulation oven at $65^{\circ} \mathrm{C}$ until constant weight, to determine their dry weight. The shoot fresh and dry weights were expressed as $\mathrm{Mg} \mathrm{ha}^{-1}$.

Subsequently, the samples were processed in a knife mill and the total nitrogen was determined according to the methodology of Kjeldahl, as described by Martins \& Reissmann (2007). The velvet bean plants were then manually cut using a brush cutter, leaving them on the soil.

Furrows were opened using a hoe for the maize sowing at 7 days after the cut of velvet bean plants. The maize seeds were manually sowed, using 25 seeds per row, starting from the plots with no inoculation treatment to avoid contamination.

The maize seeds were inoculated with diazotrophic bacteria of the species Herbaspirillum seropedicae, strain ZAE94 (BR 11417), with a population of 109 cells g $^{-1}$. The inoculant was in turf medium and was applied at rate of $250 \mathrm{~g}$ per $10 \mathrm{~kg}$ of maize seeds (Alves, 2007).

The plots with mineral nitrogen treatment were previously treated with $20 \%$ of the total dose $\left(120 \mathrm{~kg} \mathrm{ha}^{-1}\right)$ at planting. The soil fertilizer used was ammonium sulfate. The second and third nitrogen application (topdressing) was carried out at 20 and 70 days after sowing, respectively. The plants were thinned at 20 days after sowing, keeping 12 plants per row.

Cultural practices and pest control were carried out according to the needs of the crop. Three manual weeding were carried out during the experiment, the first two at the same days of nitrogen application (20 and 70 days after the sowing).

The maize was harvested on July 18, 2016, with grain moisture of approximately $25 \%$. The ears were dried in an agricultural oven until reaching approximately $13 \%$ moisture. 
The ears were then taken to the laboratory to evaluate the maize production components and grain yield.

Ten ears of each plot were randomly chosen and evaluated for ear diameter and length, using a digital caliper and a ruler, respectively. The number of grains per row was determined by counting the grains in three rows of each ear. The ear weight without husks and cob weight were evaluated using a digital balance with precision of $0.01 \mathrm{~g}$.

Maize grain yield was evaluated using all ears of the evaluation area, which were weighed in a digital balance with precision of $0.01 \mathrm{~g}$. The values were expressed as $\mathrm{Mg} \mathrm{ha}^{-1}$ after the correcting the grain moisture to $13 \%$.

The data were subjected to normality analysis by the Lilliefors test, homogeneity of variances by the Bartlett test, as recommended by Banzatto \& Kronka (2011), and analysis of variance; the means were compared by the Tukey's test at $\mathrm{p} \leq 0.05$, using the Sisvar 5.3 program (Ferreira, 2011), and the interaction was tested when its effect was significant.

\section{Results AND Discussion}

The velvet bean fresh weight yield was $45.3 \mathrm{Mg} \mathrm{ha}^{-1}$, higher than that reported by Almeida \& Camara (2011), who evaluated biomass yield in soil with green manure and found fresh weight yield of $36.7 \mathrm{Mg} \mathrm{ha}^{-1}$ for velvet bean plants at 138 days after sowing, with possible higher yield if other fertilizations and seed inoculation was used, as found in the present study for the inoculated plants.

The dry weight yield was $12.9 \mathrm{Mg} \mathrm{ha}^{-1}$, higher than those reported in other studies (Almeida \& Camara, 2011; Cavalcante et al., 2012; Silva et al., 2014; Moreira et al., 2016). This higher result is probably related to velvet bean planting season, which was in the summer, as recommended for the crop.

The total accumulated nitrogen in velvet bean plants was $40.7 \mathrm{~g} \mathrm{~kg}^{-1}$, higher than that found by Rodrigues et al. (2012). This difference may be due to the inoculation of velvet bean seeds with diazotrophic bacteria. Barradas (2010) reported that the biological nitrogen fixation efficiency increases in leguminous seeds inoculated with diazotrophic bacteria at high concentrations.

Guimarães et al. (2016) evaluated the development of pigeon pea (Cajanus cajan) seeds inoculated with symbiotic diazotrophic bacteria isolated from cowpea plants and found that this species, which is also used as green manure, responded positively to the inoculation, showing a favorable plant-bacteria interaction.
According to Silva et al. (2014), the amount of accumulated nitrogen depends on the species used, phenological stage, dry matter production, and crop season; they also found that velvet bean had, among the studied species, the highest nitrogen contribution and is recommended as a green manure, mainly for crops species with high nitrogen demand.

The nitrogen accumulation of velvet bean was approximately $170 \mathrm{~kg} \mathrm{ha}^{-1}$, which is enough to supply the nitrogen demand of the subsequent maize crop, making the maize to express its genetic potential in terms of yield.

The results of the maize hybrid subjected to the treatments showed triple interaction between the factors (green manure $x$ inoculation $\times$ nitrogen) to all analyzed characteristics (Table 1 ).

The interaction was tested considering the green manure within the inoculation and nitrogen, and the response to inoculation under absence or presence of nitrogen fertilization (Table 2).

The green manure had better results without nitrogen and inoculation $\left(\mathrm{N}_{0} \times \mathrm{I}_{0}\right)$ for all evaluated characteristics. This denotes that the green manure is enough to provide the nitrogen required for the maize crop. The use of velvet bean

Table 2. Interaction of green manure $\times$ inoculation $\times$ nitrogen for ear length, ear diameter, number of grains per row, ear weight, cob weight, and grain yield of maize plants (hybrid AG 1051) grown in Vitória of Conquista, BA, Brazil

\begin{tabular}{|c|c|c|c|c|}
\hline \multirow{2}{*}{ GM } & \multicolumn{4}{|c|}{$\mathrm{N} \times \mathrm{I}$} \\
\hline & $\mathrm{N}_{0} \times \mathrm{I}_{0}$ & $\mathrm{~N}_{0} \times \mathrm{I}_{1}$ & $\mathrm{~N}_{1} \times \mathrm{I}_{0}$ & $\mathrm{~N}_{1} \times \mathrm{I}_{1}$ \\
\hline \multicolumn{5}{|c|}{ Ear length $(\mathrm{cm})$} \\
\hline $\mathrm{GM}_{0}$ & $12.44 \mathrm{bB}$ & $14.52 \mathrm{bA}$ & $16.11 \mathrm{aA}$ & $14.41 \mathrm{bB}$ \\
\hline $\mathrm{GM}_{1}$ & $15.29 \mathrm{aB}$ & $16.56 \mathrm{aA}$ & $16.39 \mathrm{aB}$ & $15.86 \mathrm{aB}$ \\
\hline \multicolumn{5}{|c|}{ Ear diameter $(\mathrm{mm})$} \\
\hline $\mathrm{GM}_{0}$ & $46.11 \mathrm{bA}$ & $48.95 \mathrm{aA}$ & $48.85 \mathrm{bA}$ & $48.98 \mathrm{aA}$ \\
\hline $\mathrm{GM}_{1}$ & $50.29 \mathrm{aA}$ & $51.73 \mathrm{aA}$ & $52.43 \mathrm{aA}$ & $51.83 \mathrm{aA}$ \\
\hline \multicolumn{5}{|c|}{ Number of grians per row (unit) } \\
\hline $\mathrm{GM}_{0}$ & $23.33 \mathrm{bB}$ & $35.80 \mathrm{bA}$ & $38.95 \mathrm{aA}$ & $34.43 \mathrm{bB}$ \\
\hline $\mathrm{GM}_{1}$ & $37.33 \mathrm{aB}$ & $40.10 \mathrm{aA}$ & $39.55 \mathrm{aB}$ & $37.55 \mathrm{aB}$ \\
\hline \multicolumn{5}{|c|}{ Ear weight without husks $(\mathrm{kg})$} \\
\hline $\mathrm{GM}_{0}$ & $0.12 \mathrm{bB}$ & $0.16 \mathrm{bA}$ & $0.18 \mathrm{aA}$ & $0.15 \mathrm{bB}$ \\
\hline $\mathrm{GM}_{1}$ & $0.15 \mathrm{aB}$ & $0.19 \mathrm{aB}$ & $0.18 \mathrm{aB}$ & $0.17 \mathrm{aB}$ \\
\hline \multicolumn{5}{|c|}{ Cob weight $(\mathrm{kg})$} \\
\hline $\mathrm{GM}_{0}$ & $0.020 \mathrm{bB}$ & $0.025 \mathrm{bA}$ & $0.029 \mathrm{aA}$ & $0.024 \mathrm{bB}$ \\
\hline $\mathrm{GM}_{1}$ & $0.028 \mathrm{aB}$ & $0.031 \mathrm{aA}$ & $0.030 \mathrm{aB}$ & $0.028 \mathrm{aB}$ \\
\hline \multicolumn{5}{|c|}{ Grain yield $\left(\mathrm{Mg} \mathrm{ha}^{-1}\right)$} \\
\hline $\mathrm{GM}_{0}$ & $7.17 \mathrm{bA}$ & $9.88 \mathrm{aA}$ & $11.41 \mathrm{aA}$ & $11.06 \mathrm{aA}$ \\
\hline $\mathrm{GM}_{1}$ & $13.19 \mathrm{aA}$ & $11.82 \mathrm{aA}$ & $12.85 \mathrm{aA}$ & $12.38 \mathrm{aA}$ \\
\hline
\end{tabular}

Means followed by a same lowercase letter in the columns and uppercase letter in the rows within each variable are not different by the Tukey's test at $\mathrm{p} \leq 0.05$. GM - Green manure; $\mathrm{N}$ - Nitrogen; I - Inoculation; $\mathrm{AV}_{0}$ - Absence of green manure; $\mathrm{AV}_{1}$ - Presence of green manure; $\mathrm{N}_{0}$ - Absence of nitrogen; $\mathrm{N}_{1}$ - Presence of nitrogen; $\mathrm{I}_{0}$ - Absence of inoculation; $I_{1}$ - Presence of inoculation

Table 1. Analysis of variance for ear length (EL), ear diameter (ED), number of grains per row (NGR), ear weight (EW), cob weight (CW) and grain yield (GY) of maize plants (hybrid AG 1051) grown in Vitória of Conquista, BA, Brazil

\begin{tabular}{|c|c|c|c|c|c|c|c|}
\hline \multirow{2}{*}{$\begin{array}{c}\text { Source } \\
\text { of variation }\end{array}$} & \multirow{2}{*}{ DF } & \multicolumn{6}{|c|}{ Mean square } \\
\hline & & $\overline{E L}$ & ED & NGR & EW & CW & GY \\
\hline GM & 1 & $219.437^{*}$ & $895.724^{*}$ & $1283.603^{*}$ & $0.030^{*}$ & $0.002^{*}$ & $57.620^{*}$ \\
\hline $\mathrm{N}$ & 1 & 78.398* & $125.876^{\text {ns }}$ & $313.830^{*}$ & $0.026^{*}$ & $0.0002^{*}$ & $15.905^{\star}$ \\
\hline I & 1 & $6.382^{\text {ns }}$ & $72.219^{\text {ns }}$ & $37.060^{\text {ns }}$ & $0.012^{*}$ & $0.00001^{\mathrm{ns}}$ & $0.140^{\text {ns }}$ \\
\hline $\mathrm{GM} \times \mathrm{N}$ & 1 & 49.920 * & $1.355^{\star}$ & $367.439 *$ & $0.016^{*}$ & $0.0004^{*}$ & $13.546^{*}$ \\
\hline $\mathrm{GM} \times 1$ & 1 & $0.649 *$ & $22.674^{\star}$ & $6.874^{\star}$ & $0.003^{*}$ & $0.000003^{*}$ & $8.841^{*}$ \\
\hline $\mathrm{N} \times \mathrm{I}$ & 1 & 155.389* & 112.409* & $1243.859 *$ & $0.057^{\star}$ & $0.00109 *$ & $2.333^{\text {ns }}$ \\
\hline $\mathrm{GM} \times \mathrm{N} \times \mathrm{I}$ & 1 & 19.498* & $2.315^{\star}$ & 193.598* & $0.003^{*}$ & $0.000138 *$ & $7.861^{\star}$ \\
\hline CV (\%) & & 12.31 & 13.24 & 12.61 & 22.13 & 22.78 & 16.88 \\
\hline
\end{tabular}

DF - Degrees of freedom; ${ }^{*}$ - Significant at $\mathrm{p} \leq 0.05$; $^{\text {ns }}$ - Not significant by the F test; GM - Green manure; N - Nitrogen; I - Inoculation 
resulted in a good shoot dry weight and nutrient accumulation available to the succeeding crop. The soil cover with plant residues can recover, maintain, or improve soil chemical, physical, and biological properties, contributing to increase maize grain yield; this was shown through the relative increase of $1.78 \mathrm{Mg} \mathrm{ha}^{-1}$ promoted by the green manure when compared to the mineral fertilizer as nitrogen source. According to Primavesi (2002), organic matter promotes benefits to the soil, which can repair mineral unbalances caused by mineral fertilizations, reduce impacts of management errors, provide other nutrients, and increase soil buffer power, decreasing nutrient deficiency cause by excess of other nutrients.

The use of green manure resulted in higher ear length in all nitrogen $\times$ inoculation $(\mathrm{N} \times \mathrm{I})$ combinations, except in the presence of nitrogen and absence of inoculation $\left(\mathrm{N}_{1} \times \mathrm{I}_{0}\right)$, which had similar results, probably due to the nitrogen rate used, which was the recommended for the crop according to Ribeiro et al. (1999).

The use of diazotrophic bacteria with no green manure and chemical fertilizer resulted in higher ear length, number of grains per row, and ear weight, and $2.71 \mathrm{Mg} \mathrm{ha}^{-1}$ higher grain yield. Inoculations with bacteria contribute to nitrogen biological fixation and decrease the application of other fertilizers, since these microorganisms solubilize phosphate and zinc (Estrada et al., 2013), and produce siderophores and growth regulators, such as auxins, gibberellins, and cytokinins, as reported by Santi et al. (2013)

Albuquerque et al. (2013) evaluated the effect of soil cover plants and nitrogen fertilization on maize production under no-till system and found significant interaction between the leguminous species and nitrogen rate; in addition, the test of interaction showed that the use of velvet bean resulted in higher ear length when combined with the $\mathrm{N}$ rate of $80 \mathrm{~kg} \mathrm{ha}^{-1}$ when compared to the rate zero. A higher nitrogen rate was used in the present study, which probably contributed to the lack of effects of the green manure in the treatment $\mathrm{N}_{1} \times \mathrm{I}_{0}$.

The use of green manure resulted in higher ear diameter in the combinations $\mathrm{N}_{0} \times \mathrm{I}_{0}$ and $\mathrm{N}_{1} \times \mathrm{I}_{0}$, not differing from the other treatments. The velvet bean plants supplied the nitrogen needed of the maize crop due to its potential to accumulate nitrogen and low $\mathrm{C}$ to $\mathrm{N}$ ratio, which favored the nutrient availability. Similar results were found by Santos et al. (2010), who showed the benefits of green manure to ear diameter.

Lázaro et al. (2013) found no significant difference for ear diameter and attributed this result to the high organic matter content on the soil of the experimental area; this confirms the results in the present study, in which the organic matter from the velvet bean resulted in higher ear diameter.

The use of green manure resulted in higher number of grains per row in all $\mathrm{N} \times \mathrm{I}$ combinations, except in presence of mineral nitrogen and absence of inoculation $\left(\mathrm{N}_{1} \times \mathrm{I}_{0}\right)$.

The inoculation with diazotrophic bacteria resulted in a higher number of grains per row when using green manure with no mineral nitrogen, showing a positive and beneficial interaction between organic matter and microorganisms. Organic matter affects the soil characteristics, including soil moisture, temperature, nutrient availability, and aeration, allowing the proliferation of the soil microbiota. The number of grains per row is a characteristic that determine grain yield. The use of green manure without other nitrogen source $\left(\mathrm{N}_{0} \times \mathrm{I}_{0}\right)$ resulted in higher number of grains per row. Different results were found by Brito et al. (2017), with green manure promoting no differences in number of grains per row. Moreover, Santos et al. (2010) evaluated green manure and nitrogen topdressing for maize crops and found significant difference, with better results of number of grains per ear for the green manure.

The use of inoculation resulted in the highest ear weight under no green manure and nitrogen fertilization, showing that it supplied the nitrogen required for the maize crop, as well as the mineral nitrogen applied alone. The use of green manure without other nitrogen sources resulted in the highest ear weight. Santos et al. (2010) found significant interaction between green manure and mineral nitrogen fertilization, with the use of jack bean (Canavalia ensiformis) as green manure and no mineral nitrogen resulting in higher ear weight than the use of treatments with Crotalaria sp., millet, or spontaneous vegetation.

The inoculation resulted in higher cob weight when using no green manure and mineral nitrogen, and lower results were found when using nitrogen and no green manure. Diazotrophic bacteria require no energy to fix nitrogen under presence of a nitrogen source, but become inactive when they are in contact with high amount of nitrogen.

According to Zumft (1985), the activity of nitrogenase enzymes in diazotrophic bacteria are fast and reversibly inhibited when adding $\mathrm{NH}_{4}^{+}$. However, this was not found when the bacteria were combined only with green manure. Positive effect of inoculation was found because the diazotrophic bacteria require an initial nitrogen source, which may have been released slowly by the green manure and because this practice have benefits to soil, contributing to a better action of the diazotrophic bacteria. According to Primavesi (2002), biological nitrogen fixation is higher in soils with organic matter.

The green manure resulted in significantly higher grain yield under no mineral nitrogen and inoculation $\left(\mathrm{N}_{0} \times \mathrm{I}_{0}\right)$, showing the efficiency of this practice.

Several studies show results of maize plants subjected to green manure with significant difference for grain yield. For example, Pandovan et al. (2015) found higher maize grain yield in succession to velvet bean when compared to the control.

Câmara et al. (2016) evaluated green maize yield as a function of managements with soil cover plants and mineral fertilizer rates $(0 \%, 100 \%$, and $200 \%$ of the recommended rate) and found no significant difference between soil cover plants, nor between mineral fertilizer rates; they attributed this result to intrinsic characteristic of the variety studied.

Despite the lack of significant difference for the $\mathrm{N}_{0} \times \mathrm{I}_{1}$, $\mathrm{N}_{1} \times \mathrm{I}_{0}, \mathrm{~N}_{1} \times \mathrm{I}_{1}$ combinations (Table 2), the green manure resulted in increases in grain yield of $1.94,1.44$, and $1.32 \mathrm{Mg} \mathrm{ha}^{-1}$, respectively.

The specific condition for positive significance of green manure for grain yield was found when it was the single source of nitrogen $\left(\mathrm{N}_{0} \times \mathrm{I}_{0}\right)$. The green manure presents no significant differences when including inoculation with diazotrophic bacteria, or mineral fertilizer. 
The use of inoculation with no green manure and mineral nitrogen increased grain yield in $1.11 \mathrm{Mg} \mathrm{ha}^{-1}$ due to the activity of diazotrophic bacteria, denoting the effect of inoculation with Herbaspirillum seropedicae.

Dartora et al. (2013) evaluated soil nitrogen fertilization combined with inoculation with Azospirillum brasilense and Herbaspirillum seropedicae on maize crops and found no significant effect of inoculation on grain yield, but a relative increase of $0.922 \mathrm{Mg} \mathrm{ha}^{-1}$ in grain yield for plants under inoculation with two strains, when compared to the control. This confirms that the inoculation with bacteria in the present study can be applied to maize crops.

\section{Conclusions}

1. Velvet bean can be used as green manure for maize crops, as an alternative to chemical nitrogen fertilizers.

2. The inoculation of maize seeds of the cultivar AG 1051 with Herbaspirillum seropedicae increases the grain yield of the plants.

3. The interaction between green manure and inoculation with Herbaspirillum seropedicae had positive effects on the maize characteristics ear length, number of grains per row, and cob weight.

\section{ACKNOWLEDGMents}

We thank the Universidade Estadual do Sudoeste da Bahia (UESB) for the assistance from the Internal Financial Assistance Program for Research and Innovation Projects (AUXPPI-PAR 2018), the Coordenação de Aperfeiçoamento de Pessoal de Nível Superior (CAPES) for the granting of the master's scholarship and the Conselho Nacional de Desenvolvimento Científico e Tecnológico (CNPq) through the Edital Universal process 460862/2014-6.

\section{Literature Cited}

Albuquerque, A. W. de; Santos, J. R.; Moura Filho, G.; Reis, L. S. Plantas de cobertura e adubação nitrogenada na produção de milho em sistema de plantio direto. Revista Brasileira de Engenharia Agrícola e Ambiental, v.17, p.721-726, 2013. https:// doi.org/10.1590/S1415-43662013000700005

Almeida, K. de; Camara, F. L. A. Produtividade de biomassa e acúmulo de nutrientes em adubos verdes, em cultivos solteiros e consorciados. Revista Brasileira de Agroecologia, p.55-62, 2011.

Alves, G. C. Efeito da inoculação de bacterias diazotróficas dos gêneros Herbaspirillum e Burkholderia em genótipos de milho. 2007. 53p. UFRRJ: Rio de Janeiro. Dissertação Mestrado

Banzatto, D. A.; Kronka, S. N. 2011. Experimentação agrícola. 4.ed. Jaboticabal: FUNP. 237p.

Barradas, C. A. A. Uso da adubação verde. Niterói - RJ: Programa Rio Rural, 2010. 10p. Manual Técnico 25.

Brito, M. F.; Tsujigushi, B. P.; Rocha, D. P.; Silva, R. F. Reciclagem de nutrientes de adubos verdes e produtividade de milho cultivado em sucessão em agroecossistema de transição agroecológica. Acta Iguazu, v.6, p.11-21, 2017.
Camara, F. T. da; Gondim, H. T.; Mota, A. M. D.; Nicolau, F. E. A.; Brito, L. L. M. de; Máximo, P. J. M.; Silva, J. M. F. da. Produtividade de milho verde em função do manejo da adubação na região do cariri cearense. Revista Cultivando o Saber, v.9, p.412-425, 2016.

Cavalcante, V. S.; Santos, V. R.; Santos Neto, A. L.; Santos, M. A. L.; Santos, C. G.; Costa, L. C. Biomassa e extração de nutrientes por plantas de cobertura. Revista Brasileira Engenharia Agrícola e Ambiental, v.16, p.521-528, 2012. https://doi.org/10.1590/S141543662012000500008

CONAB - Companhia Nacional de Abastecimento. Acompanhamento da Safra Brasileira de grãos. Brasília, v.4. 2017. 160p.

Dartora, J.; Guimarães, V. F.; Marine, D.; Sander, G. Adubação nitrogenada associada à inoculação com Azospirillum brasilense e Herbaspirillum seropedicae na cultura do milho. Revista Brasileira de Engenharia Agrícola e Ambiental, v.17, p.10231029, 2013. https://doi.org/10.1590/S1415-43662013001000001

Estrada, G. A.; Baldani, V. L. D.; Oliveira, D. M. de; Urquiaga, S.; Baldani, J. I., Selction of phosphate-solubilizing diazotrophic Herbaspirillum and Burkholderia strains and their effect on rice crop yield and nutriente uptake. Plant and Soil, v.369, p.115-129, 2013. https://doi.org/10.1007/s11104-012-1550-7

Ferreira, D. F. Sisvar: A computer statistical analysis system. Ciência e Agrotecnologia, v.35, p.1039-1042, 2011. https://doi. org/10.1590/S1413-70542011000600001

Guimarães, S. L.; Neves, L. C. D. das.; Bonfim-Silva, E. M.; Campos, D. T. S. Development of pigeon pea inoculated with Rhizobium isolated from cowpea trap host plants. Revista Caatinga, v.29, p.789-795, 2016. https://doi.org/10.1590/198321252016v29n402rc

Hungria, M.; Franchini, J. C.; Campo, R. J.; Crispino, C. C.; Moraes, J. Z.; Sibadelli, R. N. R.; Mendes, I. C.; Arihara, J. Nitrogen nutrition of soybean in Brazil: Contributions of biological $\mathrm{N}_{2}$ fixation and of $\mathrm{N}$ fertilizer to grain yield. Canadian. Journal of Plant Science, v.86 p.927-939, 2006. https://doi.org/10.4141/ P05-098

Kappes, C.; Arf, O.; Arf, M. V.; Ferreira, J. P.; Dal Bem, E. A.; Portugal, J. R.; Gonçalves, V. R. Inoculação de sementes com bacteria diazotrófica e aplicação de nitrogênio em cobertura e foliar em milho. Semina: Ciências Agrárias, v.34, p.527-538, 2013. https:// doi.org/10.5433/1679-0359.2013v34n2p527

Lázaro, R. de L.; Costa, A. C. T. da; Silva, K. F. da; Sarto, M. V. M.; Duarte Júnior, J. B. Produtividade de milho cultivados em sucessão à adubação verde. Pesquisa Agropecuaria Tropical, v.43, p.10-17, 2013. https://doi.org/10.1590/S198340632013000100008

Malavolta, E. Manual de nutrição mineral de plantas. São Paulo: Editora Ceres, 2006. 638p.

Martins, A. P. L.; Reissmann, C. B. Material vegetal e as rotinas laboratoriais nos procedimentos químico-analítico. Scientia Agraria, v.8, p.1-17, 2007. https://doi.org/10.5380/rsa.v8i1.8336

Moreira, D. G.; Vieira, M. C.; Heredia Zarate, N. A.; Carnevali, T.O.; Torales, E. P.; Tabaldi, L. A. Lourente, E. R. P.; Mercante, F. M. Produtividade de vinagreira, pimenta rosa e carobinha cultivadas em sucessão a mucuna preta e feijão de porco. Revista Brasileira de Plantas Medicinais, v.18, n.1, p.326-335, 2016. https://doi. org/10.1590/1983-084X/15_085 
Pandovan, M. P.; Carneiro, L. F.; Felisberto, G. Nascimento, J. S.; Carneiro, D. N. M. Milho cultivado em sucessão a adubos verdes em sistemas de bases agroecológicas. Revista Agroambiente, v.9, p.377-385, 2015. https://doi.org/10.18227/1982-8470ragro. v9i4.2705

Primavesi, A. Manejo ecológico do solo: A agricultura em regiões tropicais. São Paulo: Ed. Nobel, 2002. 541p.

Ribeiro, A. C.; Guimarães, P. T. G.; Alvarez V., V. A. H. Recomendação para uso de corretivo e fertilizantes em Minas Gerais - $5^{a}$ Aproximação. Viçosa, Ed. UFV, 1999, 359p.

Rodrigues, G. B.; Sá, M. E. de; Valério Filho, W. V.; Buzetti, S.; Bertolin, D. C.; Pina, T. P. Matéria e nutrientes da parte aérea de adubos verdes em cultivos exclusivo e consorciado. Revista Ceres, v.59, p.380-385, 2012. https://doi.org/10.1590/S0034737X2012000300013

Santi, C.; Bogusz, D.; Franche, C. Biological nitrogen fixation in nonlegume plant. Annals of Botany, v.111, p.743-767, 2013. https:// doi.org/10.1093/aob/mct048
Santos, P. A.; Silva, A. F. da; Carvalho, M. A. C. de; Caione, G. Adubos verdes e adubação nitrogenada em cobertura no cultivo do milho. Revista Brasileira de Milho e Sorgo, v.9, p.123-134, 2010. https:// doi.org/10.18512/1980-6477/rbms.v9n2p123-134

SEI - Superintendência de Estudos Econômicos e Sociais da Bahia. Estatísticas dos Municípios Baianos. Salvador, v.4, 2013, p.433-452. Silva, M. P. da; Arf, O.; Sá, M. E. de; Abrantes, F. L.; Berti, C. L. F.; Souza, C. D. de; Arruda, N. Palhada, teores de nutrientes e cobertura do solo por plantas de cobertura semeadas no verão para semeadura direta do feijão. Revista Agrarian, v.7, p.233243, 2014.

Zambolim, L.; Ventura, J. A.; Zanão Junior, L. A. Efeito da nutrição mineral no controle de doenças de plantas. Viçosa:, 2012. 321p.

Zumft,W.G. Regulation of nitrogenaseactivityin theanoxygenicphototrophic bacteria. In: Evans, H. J., Bottomley, P. J., Newton, W. E. (eds.) Nitrogen fixation research progress. Current Plant Science and Biotechnology in Agricuture, vol 1. Dordrecht: Springer.1985. p. 551-557. https://doi. org/10.1007/978-94-009-5175-4_76 